own territory are consistent with sound commercial policy. ${ }^{43}$ Thus it would appear that enactment of the Code would dispel much of the confusion about the measure of damages for breach of an "irrevocable" commercial letter of credit.

${ }^{48}$ It has been urged, however, that it would be better policy to advance the point when a credit becomes incontestable, and thus to avoid, so far as possible, postponing the beneficiaryseller to the vagaries and delay of a damage action. Steffen, Irrevocable Credits and the Law, - J. Business Law - (London, 1958).

\title{
A CRITICAL ANALYSIS OF RULES AGAINST SOLICITATION BY LAWYERS
}

Although several of the ancient rules regulating the professional conduct of lawyers have been discarded in America, ${ }^{1}$ those prohibiting the solicitation ${ }^{2}$ of professional employment have gone almost unchallenged. ${ }^{3}$ Writers on the subject of solicitation have tended to limit their treatment to a description of the rules and have not undertaken a critical examination of the reasons given for those rules. The approach taken by the writers may in some measure be justifiable. A critical analysis of the rules must of necessity be inadequate, for the rules are based in part on deeply ingrained feelings of tradition, ${ }^{5}$ honor and service. Lawyers have for centuries emphasized that the promotion of justice, rather than the earning of fees, is the goal of the profession. Moreover, it is felt that solicitation, with its emphasis on economic ends, may hamper the establishment of the proper attorney-client relationship. These considerations, seldom articulated, will have to be weighed in the final evaluation of the rules against solicita-

1 The outstanding example is the elimination of the rule against contingent fees. See generally Radin, Maintenance by Champerty, 24 Cal. L. Rev. 48 (1935).

2 The Canons of Professional Ethics make a distinction between advertising and direct solicitation. Canons 27 and 28, A.B.A., Canons of Professional Ethics (1957). The comment will be devoted primarily to the latter and will assume that any doubts concerning the present rules against direct solicitation would apply with equal or greater force to the rules against advertising. Compare the dissent in In re Schwarz, 231 N.Y. 642, 132 N.E. 921 (1921) (advertising) with People v. Culkin, 248 N.Y. 465, 162 N.E. 487 (1928) (direct solicitation).

'At least two significant challenges have occurred. With his article, The Bugaboo, "Ambulance Chasing," 6 Cal. S. B.J. 37 (1931), James F. Brennan provoked a flurry of controversy in the pages of the California State Bar Journal. Recently Mr. Justice Bristow of the Illinois Supreme Court said that he was unable to reconcile the rules against solicitation with the condoned practice of gaining clients at country clubs. In re Cohn, $10 \mathrm{ml} .2 \mathrm{~d} 186,196,139$ N.E.2d 301,306 (1956) (concurring opinion).

4 See, e.g., Drinker, Legal Ethics 64 (1953); Ambulance Chasing, 30 N.Y.U. L. Rev. 182 (1955); Advertising, Solicitation, and Legal Ethics, 7 Vand. L. Rev, 677 (1954); Settlement of Personal Injury Cases in the Chicago Area, 47 Nw. U. L. Rev. 895 (1953).

${ }^{5}$ It should, however, be emphasized that the ability of the legal profession to adjust to changes in rules governing its conduct ought not to be underestimated. In its long history the profession has adjusted to several such changes. See Lawyer's Tightrope-Use and Abuse of Fees, 41 Cornell L. Q. 683, 684-89 (1956), for a discussion of the profession's adjustment first to the fee and later to the contingent fee. 
tion. This, however, enhances rather than decreases the value of an objective analysis of those rules. Such an analysis, indeed, by clearing away false issues, is a prerequisite to a full understanding of the rules. Such an analysis, moreover, seems particularly desirable since solicitation has come to have important ramifications in areas as far removed from legal ethics as industrial injuries ${ }^{6}$ and race relations. ${ }^{7}$

Canon 27 contains an extremely broad prohibition of solicitation: "It is unprofessional to solicit professional employment... through touters or by personal communications or interviews not warranted by personal relations."8 Five major reasons have been advanced in support of this prohibition. It has been argued that solicitation results in the stirring up of litigation, in fraudulent practices, corruption of public officials, detriment to the legal profession, and harm to the solicited clients. By examining these reasons, this comment will attempt to set up an analytic framework within which the rules pertaining to solicitation may be considered. The benefits which solicitation may provide for clients, while important enough to warrant separate treatment, have been placed, for the sake of simplicity, with the discussion of the reasons advanced against solicitation. ${ }^{7}$

Stirring up litigation.-One of the oldest charges against solicitation is that it results in "stirring up litigation." That phrase had its origin in medieval English law. By the fourteenth century the English had made the stirring up of litigation a crime, ${ }^{9}$ apparently because the courts of that time were easily corrupted, ${ }^{10}$ especially by powerful lords. It was thought that if a claim was stirred up it was particularly likely to be one where the person who instigated it had control over the result. " A vestige of this feeling maylie behind modern prohibitions of solicitation. It may be thought that some soliciting lawyers are likely to have "fixed" the court system. On the one hand, insofar as this position is sound, it would seem that the proper solution is not to prohibit solicitation but to improve the measures against corruption. On the other hand, it seems fair to assume that a very large percentage of the courts will act impartially. Therefore, some reason other than the likelihood that the courts may be corrupt must be found if solicitation is to be prohibited on the ground that it stirs up litigation.

One such reason might be that it is felt that the substantive law is defective

- In re Brotherhood of Railroad Trainmen, 13 IIl.2d 391, 150 N.E.2d 163 (1958).

TN.A.A.C.P. v. Patty, 159 F.Supp. 503 (E.D. Va., 1958).

8 A.B.A. Canons of Professional and Judicial Ethics 19 (1957).

- Winfield, History of Conspiracy and Abuse of Legal Procedure 142 (1921).

${ }^{10}$ Radin, op. cit. supra note 1, at 59. Corroboration of this thesis can be found in the use of the word "barratry" to denote an offense very similar to maintenance. See IIl. Rev. Stat. (1957) c. $38, \$ \$ 65,66$. In Scotland, the word "barratry" refers to a judge's receipt of a bribe. Winfield, op. cit. supra note 9, at 201. See also Offense of Barratry; Criminal Aspects of Champerty and Maintenance, 139 A.L.R. 620 (1942). (1838).

1] Winfield, op. cit. supra note 9, at 142-45. See also Holloway v. Lowe, 7 Port. (Ala.) 488 
and that injustice will result to one of the parties if a suit is stirred up. ${ }^{12}$ However, if the bringing of certain types of suit leads to unjust results, courts should, it would seem, decline to entertain all such suits, not merely those which have been solicited. Any attack should be directed not at solicitation but rather at the substantive law. To the extent that rules against solicitation diminish the demand for improvement of the substantive law, they perform a disservice. ${ }^{13}$

A more persuasive reason to discourage the stirring up of litigation might be found in the theory behind the establishment of courts. It can be argued that the function of the court system is to serve as an impartial tribunal to which disputants can refer their contentions instead of using socially disruptive means of settlement. Under this theory, which emphasizes the peace of the community, it would seem that the judicial machinery is designed to serve only persons who feel sufficiently aggrieved to bring forward their claims on their own volition. If this is true, stirring up litigation is clearly undesirable. However, if individual rights be emphasized and the theory be adopted that the function of the courts is to enforce all valid claims, ${ }^{14}$ then stirring up litigation must be considered a

12 This contention was considered and rejected in Hovey v. Hobson, $51 \mathrm{Me} .62$ (1863). The case of Backus v. Byron, 4 Mich. 535 (1857), suggests a similar argument: if solicitation is permitted, earlier transactions may be upset because of the mistakes of the lawyers involved in those transactions. This argument may be true; it would seem, however, that the proper solution is to improve the level of legal craftsmanship. The substantive law involved in the Hovey and Backus cases was that of adverse possession. Another area of the law which may also have affected the attitude of courts towards solicitation is that of deficiency judgments. See Petition of Hubbard, 267 S.W.2d 743 (Ky., 1954).

13 The abolition of the action for personal injuries caused by automobile accidents has been recommended because of the difficulty encountered in enforcing rules against solicitation of this action. See Drinker, Legal Ethics 64 (1953); Report of the Committee of Censors, Philadelphia Bar Ass'n, 14 Mass. L. Q. Supp. 59 (1928). This recommendation assumes that the evils of solicitation outweigh the benefits accruing to society from the maintenance of the actions. Unless the validity of this assumption can be clearly demonstrated, the abolition of the cause of action would seem unwise.

14 This theory is based on the contention that the failure of a plaintiff to obtain judgment is in effect judgment for the defendant and that this arbitrarily discriminates against the former. Radin, op. cit. supra note 1, at 69, 77-8. 2 Thornton, Attorneys at Law $\$ 383$ (1914). However, this is a broad contention, which may require some refinement.

Prior to solicitation the potential claimant may have allowed his claim to go unasserted for one of three reasons: ignorance, knowledge coupled with lethargy, and knowledge coupled with an unwillingness to assert his claim.

In the first situation it would appear that solicitation performs a desirable function in informing persons of their legal rights. Such, however, does not appear to be the law. In the case of In re Clark, 184 N.Y. 222, 77 N.E. 1 (1906), landowners were solicited for claims against a telegraph company; in Gammons v. Johnson, 76 Minn. 76, 78 N.W. 1035 (1899), landowners were solicited for claims against a railroad. In both cases the solicitation was held improper. Such decisions must assume that it is preferable that the landowner bear the cost of injury to his property even though that injury was caused by another person who could be held liable if the case were tried. There seems to be little merit in this assumption.

Where the potential claimant is merely lethargic the desirability of solicitation is less clear. Assuming that the claimant's loss is not an important factor in this situation, solicitation will be desirable only if the gain to society from the assertion of valid claims at least counterbalances the additional costs of adjudication. See note 15 infra.

In the third situation, it seems clear that if a potential claimant, having been fully informed, 


\section{desirable activity. ${ }^{15}$}

It is outside the purview of this comment to decide between the two theories. It is sufficient to note that regardless of which theory is adopted, in particular actions the decision whether to encourage or discourage suits will be dictated by compelling practical reasons. Thus, some actions are undesirable because the parties are in a close personal relationship ${ }^{16}$ and, therefore, the disputes can be

is disinclined to prosecute his claim, he ought not be compelled to do so. The refusal to prosecute may be regarded as a gift which it is the potential claimant's privilege to confer. However, since the consent of the claimant is a requisite to the assertion of a claim, in this situation solicitation would not result in stirring up litigation.

${ }^{15}$ Even if this theory of the function of the courts is assumed to be the correct one, there might still be countervailing policies against the stirring up of litigation.

1. Protection of defendants: It would seem unreasonable to put defendants to the time and expense involved in defending against claims of little merit. One possible method of protecting them is to prevent such claims from being asserted. At one time, for example, it was felt that unless a plaintiff were willing to place a financial stake in the outcome of his claim, it was likely that that claim had little merit. For this reason legal aid programs were long opposed and, where they were permitted, the unsuccessful plaintiff was on occasion subjected to corporal punishment. Maguire, Poverty and Civil Litigation, 36 Harv. L. Rev. 361 (1923). The contingent fee long was opposed on similar grounds. Backus v. Byron, 4 Mich. 535,551 (1857). From the fact that legal aid and the contingent fee have become recognized, it would appear that the policy of protecting the defendant by inhibiting the assertion of claims has largely been abandoned.

Indeed, it would appear more reasonable to compensate the defendant after the claim's lack of merit has been established, rather than excluding the claim from being heard. Where the claim is brought for malicious reasons, the defendant has an action for malicious prosecution or abuse of process. Prosser, Torts $\$ \$ 98-100$ (1955). There would seem to be reason to extend analogous protection to the successful defendant in a truly frivolous claim. This protection might take the form of the English "costs." See Jackson, The Machinery of Justice in England c. V (1953). If this approach is adopted, protection of the defendant would be achieved without any necessity of inhibiting the stirring up of litigation.

2. Economy in government. It could be argued that the policy of reducing the cost of judicial administration is sufficiently important to outweigh the policy of enforcing all valid claims. However, no authority has been found supporting the argument. In Morris v. Pennsylvania R. Co., the Illinois Appellate Court said, "It is, therefore, clearly apparent that solicitation not only brings the legal profession into disrepute, but it also increases the burden of expense in operating our courts and is one of the principal factors creating the overwhelming backlog of negligence cases, which results in litigants waiting about four and one-half years for a trial in the Circuit and Superior Courts of Cook County." 10 Ill.App.2d 24, 38, 134 N.E.2d 21, 27 (1956). However, the court was referring to accidents which occurred in another jurisdiction. The court was arguing that the cost of litigation should be borne by other jurisdictions, not that such costs should not be borne at all. Moreover, it is doubtful that solicitation leads to the concentration of claims in one jurisdiction with an accompanying overcrowding of courts in that jurisdiction. The concentration presumably occurs simply because plaintiffs' attorneys believe that recovery will be larger in a particular jurisdiction. Such a belief is completely unconnected with the presence or absence of solicitation.

${ }^{16} \mathrm{It}$ has been argued that solicitation was prohibited because in the Middle Ages, when the rules were first formulated, litigation almost invariably involved persons in a close personal relationship. See Justice Bristow's concurring opinion in In re Cohn, 10 Ill.2d 186, 192, 139 N.E.2d 301, 304 (1957). In this view, as society has become more complex and impersonal, the stirring up of litigation has become less of an evil. However, as the text indicates, even today there are certain actions where solicitation should be discouraged because of the existenceof a close personal relationship. 
best settled when the possibility of judicial decision is kept from the minds of the parties. This is true of marital disputes ${ }^{17}$ and perhaps of probate matters. ${ }^{18} \mathrm{Con}-$ versely, there are several types of suit with respect to which solicitation should be and has been condoned. There is much reluctance to penalize solicitation of actions brought to enforce certain laws, ${ }^{19}$ to test certain issues of public significance $^{20}$ or to implement special public policies. ${ }^{21}$ At least in these instances, it would appear that the merit of stirring up the actions can be best appraised in terms of each particular action.

Fraudulent claims. - It has been charged that solicitation leads to the bringing of fraudulent claims..$^{22}$ This charge, even more clearly than the contention that solicitation stirs up litigation, seems best evaluated in terms of particular actions. In those suits where fraud can be easily detected, the problem of the fraudulent

${ }^{17}$ Cases are collected in Encouraging Divorce Litigation as Ground for Disbarment or Suspension, 9 A.L.R. 1318 (1928). Radin, op. cit. supra note 1, at 74 n. 93, argues that divorce litigation is discouraged because it is an evil. For reasons set out in the text and notes 12 and 13 supra, the fact of personal relationship would appear to offer a better rationale.

I8 Cases are collected in "Heir-hunting" as Ground for Disciplinary Action against Attorney, 171 A.L.R. 351 (1947). "Heir-hunting" has been disapproved primarily because the heir receives no benefit from notification and representation by the "heir-hunter," the official channel for discovery and notification being deemed adequate. Thus the "heir-hunter" in most cases merely adds to the expense of closing the estate. See In re Lynch's Estate, 154 N.Y.Misc. 260, 276 N.Y.Supp. 939 (Surr.Ct., 1935).

${ }^{19}$ N.A.A.C.P. v. Patty, 159 F.Supp. 503, 532 (E.D. Va., 1958) (civil rights); Gunnels v. Atlanta Bar Ass'n, 191 Ga. 366, 12 S.E.2d 602 (1940) (usury legislation).

20 The A.B.A. Committee on Professional Ethics found nothing unprofessional in the program of lawyers connected with the American Liberty League. A.B.A., Opinions of the Committee on Professional Ethics and Grievances 289 (1936). These lawyers, with considerable publicity, offered to supply legal assistance to persons who felt that their constitutional rights were infringed by legislation on which the League had expressed an opinion. The A.B.A. Committee, as in the Patty and Gunnels cases, note 19 supra, relied on the lawyers' absence of pecuniary motives, but this in no way alters the fact that litigation was stirred up. For additional evidence that the significant factor is the type of litigation stirred up see note 21 infra.

${ }^{21}$ The clearest example is the stockholder's derivative action, particularly the security holder's action against "insiders" under Section 16(b) of the Securities Exchange Act of 1934, 48 Stat. 896 (1934), 15 U.S.C.A. $\$ 78$ p (1951). Possible violation of a state statute prohibiting solicitation was held irrelevant to the question whether attorney's fees should be awarded in Magida v. Continental Can Co., 231 F.2d 843 (C.A.2d, 1956), cert. denied, 351 U.S. 972 (1956). There would appear to be two factors making solicitation of this action desirable: a clear policy in favor of the action and the likelihood that the action would not be brought except as a result of solicitation. Where the latter factor is absent, courts may be less liberal in their award of fees. Compare Smolowe v. Delendo Corp., 136 F.2d 231 (C.A.2d, 1943), with Milwaukee Towne Corp. v. Loew's, Inc., 190 F.2d 561 (C.A.7th, 1951), a treble damage action under Section 4 of the Clayton Act, 38 Stat. 731 (1915), 15 U.S.C.A. \$15 (1951).

Courts have been reluctant to award attorney's fees where the stockholder acts as his own attorney. E.g., Eisenberg v. Central Zone Property Corp., 1 App.Div.2d 353, 149 N.Y.S.2d 840 (1956); Ontjes v. MacNider, 234 Iowa 208, 12 N.W.2d 284 (1943). But this reluctance does not seriously impede the bringing of derivative suits; moreover, it prevents an overt flouting of Jegal ethics and preserves the fiction that the aggrieved stockholder is the initiating person.

2 See, e.g., Ambulance Chasing, 30 N.Y.U. L. Rev. 182, 187 (1955); Settlement of Personal Injury Cases in the Chicago Area, 47 Nw. U. L. Rev. 895, 898 (1953). 
claim is unimportant save as itrelates to the question of overcrowding the courts. ${ }^{23}$ Where, however, because of the technical nature of the evidence fraud is likely to pass disguised as a difference of expert opinion, methods of discouraging fraud take on significance. The outstanding example is the personal injury claim where medical testimony plays a major role. ${ }^{24}$

Even in those actions where fraud is difficult to detect, however, it is by no means obvious that solicitation increases the likelihood of fraud. It is true that if solicited claims are less likely to be valid there might exist a temptation to buttress such claims with fabricated evidence. But it is questionable whether solicited claims are less likely to be valid, at least if it is assumed that such claims are usually solicited on a contingent fee basis. Any temptation the lawyer might have to exaggerate the validity of the claim in order to secure employment is reduced by the fact that there will be no compensation if the claim is invalid. ${ }^{25}$

If a claim is solicited with the thought in mind of resorting, if necessary, to fraud, the claim might be less meritorious than other claims. It may be argued that soliciting lawyers are more likely to have fraudulent motives than other lawyers. This argument is usually based on an evaluation of those lawyers who now solicit. ${ }^{26}$ Even if this evaluation be correct, however, the retention of rules prohibiting solicitation is not justified. Rules against an activity tend to drive away persons of high morality. Assuming the repeal of the present rules, there seems to be little reason to expect solicitation to attract a disproportionate number of unscrupulous persons.

Nevertheless, in some ways solicitation will probably increase the number of fraudulent claims. For even if only a few soliciting lawyers are dishonest, fraud may be encouraged because the soliciting lawyer not only suggests to the claimant the possibility of asserting a fraudulent claim, but also assures him of professional support in prosecuting his suit. ${ }^{27}$ Absent solicitation, the idea of

${ }^{23}$ See note 15 supra.

"Proof of fraud would usually require the cooperation of either the claimant or the doctor. Because of fear of prosecution for perjury, such proof is difficult to obtain.

$\approx$ If it is true that claims represented on a contingent-fee basis are of at least average merit, opposition to the contingent fee on the ground that defendants would be subject to unjustified expenses seems unwarranted. See note 15 supra.

${ }^{36} \mathrm{~A}$ refinement of this argument is that solicitation is often carried on by persons with even lower morality than that characteristic of soliciting lawyers. Courts have at times distinguished between solicitation conducted personally by the lawyer and solicitation through lay agents; the latter type has been considered more reprehensible. The cases are collected in Advertising, Solicitation and Legal Ethics, 7 Vand. L. Rev. 677, 686 (1954). To some extent the distinction is based on the theory that the moral level of laymen is lower than that of lawyers. See State $v$. Rubin, 201 Wis. 30, 229 N.W. 36 (1930); Chreste v. Commonwealth, 171 Ky. 77, 186 S.W. 919 (1916). Support for this theory could be found in the fact that applicants to the bar must make a satisfactory showing of character and fitness. Moreover, lawyers are subject to greater sanctions, namely deprivation of their means of livelihood. However, if the lawyer is held accountable for the acts of his lay agents, the moral level of the latter should be expected to approach the moral level of the lawyer.

${ }^{n 7}$ Report of the Committee of Censors, op. cit. supra note 13, at 44 . 
bringing a fraudulent suit might never occur to the potential claimant. Even if such an idea occurred to a few claimants it is unlikely that they would have the temerity to approach a lawyer selected at random. A lawyer could make contact with such persons either by direct solicitation or through a reputation of willingness to handle fraudulent claims. He would probably prefer solicitation since a smaller group would become aware of his lack of scruples. If solicitation were effectively prohibited the dishonest lawyer would handle fewer fraudulent claims because of the greater risk of discovery and prosecution if he acquired a reputation of handling such suits.

Not only does solicitation seem to make easier the initial meeting between the dishonest lawyer and the dishonest claimant, it also places the lawyer in contact with persons, such as policemen, ${ }^{28}$ doctors ${ }^{29}$ and hospital attendants, ${ }^{30}$ who are in a position to manufacture evidence. These persons have an inducement to fabricate evidence since their remuneration may depend upon the amount of the plaintiff's recovery. ${ }^{31}$

Corruption of public officials.-The charge that solicitation results in the corruption ${ }^{32}$ of public officials seems valid. As indicated in the previous section, the soliciting lawyer will often pay doctors, hospital attendants and policemen for information about prospective clients. Since the informant's speed in notification is often a requisite for his reward, at least in cases of personal injury the immediate needs of the injured party may be subordinated. ${ }^{33}$ Even if the injured party receives proper attention, the public as a whole may suffer. The morale of any group devoted to public service will likely decline if individual

${ }^{28}$ Id., at 12-15. For cases illustrating the connection between solicitation and police officials see In re Salus, $321 \mathrm{~Pa} .103,84$ Atl. 69 (1936), incorporating by reference In re Disbarment Proceeding, 321 Pa. 81, 184 At]. 59 (1936); In re H-S-, 229 Mo.App. 44, 69 S.W.2d 325 (1934). See also In re Vail, 228 App.Div. 217, 239 N.Y.Supp.414 (1930); In re Gondelman, 225 App.Div. 462, 233 N.Y.Supp. 343 (1929). In the $H-S-$ case the lawyer also attempted to bribe the policeman to confound competing attorneys by falsifying the accident report to have it appear that the potential defendant did not carry liability insurance.

${ }^{29}$ Report of the Committee on Censors, op. cit. supra note 13, at $40-46$. For cases illustrating the connection between solicitation and the medical profession, see In re Mitgang, 385 Ill. 311, 52 N.E.2d 807 (1944); In re Robinson, 229 App.Div. 119, 241 N.Y.Supp. 296 (1930). See also Settlement of Personal Injury Cases in the Chicago Area, 47 Nw. U. L. Rev. 895, 898 (1953).

${ }^{30}$ See Settlement of Personal Injury Cases in the Chicago Area, 47 Nw. U. L. Rev. 895, 898 (1953).

al Report of the Committee on Censors, op. cit. supra note 13, at 40.

s2 As used in this section, "corruption" does not refer only to the inducing of conscious violation of duty. Rather, it refers to any transaction between an employee and a third person which reduces the value of the employee's services or of those of his fellow employees.

${ }^{33}$ Report of the Committee on Censors, op. cit. supra note 13 , at 14 . In a criminal case the interests of the client may also suffer. In one case the police employed by a soliciting attorney. not only informed the lawyer about the arrest of persons for serious traffic violations, but they also prevented other lawyers from interviewing the arrested persons. In re Salus, $321 \mathrm{~Pa} .103$, 84 Atl. 69 (1936). At the least, the speed with which the arrested persons could obtain bail was. reduced. 
members receive independent rewards from private sources for services rendered while on duty. ${ }^{34}$ This is particularly true if the private services might conflict with the public duty. ${ }^{35}$

Although it may thus be argued that solicitation corrupts public officials, this objection has force only with respect to those actions in which public officials can act as informants. ${ }^{36}$ Moreover, even with respect to such actions, it would seem that prohibiting solicitation is an indirect and inadequate ${ }^{37}$ method of doing what should be done directly, namely the elimination of payments to officials. Therefore, although solicitation may tend to corrupt public officials, the retention of the rules against solicitation is not thereby justified.

Detriment to the legal profession. - The fourth major charge which has been made against solicitation is that it harms the legal profession by injuring its reputation and by concentrating business in the hands of a few lawyers.

It has been argued that the public will lose respect for the profession if lawyers seek financial gain rather than the achievement of justice. ${ }^{38}$ From this, it is asserted, will follow disrespect for the legal process and orderly government. ${ }^{39}$ The first portion of the argument is open to two objections. First, public revulsion at the aggressive pursuit of financial gain may be too readily assumed since a large and respected portion of the population is engaged in just such a pursuit. Second, the concept of the lawyer as a disinterested champion of justice is at odds with the adversary system of justice ${ }^{40}$ and is a notion which, moreover, any potential client would, upon reflection, vigorously repudiate. Equally questionable is the second portion of the argument, that disrespect for lawyers leads to a disrespect for law. For many centuries in England lawyers have been denounced by moralists and have played the villian's role in literature; yet to an

${ }^{34}$ For example, in a civil service system increases in pay are proportioned to the quality of work performed. When there are private sources of remuneration, the incentive to improve the quality of work is reduced.

${ }^{35}$ See note 28 supra.

${ }^{3}$ This argument might also apply to other groups, such as private police forces, where loyalty to employers is particularly important.

${ }^{37}$ Not only could lawyers be prohibited from making payments to public officials, the receipt of such payments could legitimately be made grounds for discharge from employment. Such rules would appear easier to enforce than rules prohibiting solicitation.

${ }^{28}$ See, e.g., Mayer v. State Bar, 2 Cal.2d 71, 39 P.2d 206 (1934). It would seem, however, that even if rules against solicitation were repealed there are other and more direct methods of demonstrating a concern for public service.

${ }^{39}$ This is perhaps an extreme statement of the conclusions reached in Phillips and McCoy, Conduct of Judges and Lawyers 188-214 (1952). It would, however, appear to be a necessary step in the argument; otherwise persons could be deprived of a livelihood for no reason other than professional vanity.

${ }^{40}$ See Riesman, Some Observations on Law and Psychology, 19 U. of Chi. I. Rev. 30, 34 (1951). Riesman argues that for the lawyer to fulfill his role in society it is necessary for him to incur some measure of public distrust.

11 See Pound, Introduction to Law in Action (1947); see also references in Cohen, The Law: Business or Profession? c. II (1916). 
unparalleled degree law has flourished in England as the organizing principle of society.

It has also been argued that solicitation works to the detriment of the legal profession by concentrating legal business in the hands of a few lawyers. However, to the extent that the present rules against solicitation are inadequately enforced, the rules themselves encourage concentration by putting the more scrupulous lawyer at a competitive disadvantage. ${ }^{42}$ Moreover, although it may be asserted that entry of a young lawyer into a field where solicitation is permitted is more difficult because of the capital required to establish a solicitation system, ${ }^{43}$ it would seem more likely that the rules against solicitation themselves actually prevent a young lawyer from establishing himself. ${ }^{44}$

Harm to the client.-The last major charge against solicitation is that it harms the client. ${ }^{45}$ This charge has three elements: overreaching, overcharging and underrepresentation.

12 Advertising, Solicitation, and Legal Ethics, 7 Vand. I. Rev. 677, 684 (1954), contains an argument to the converse: rules against solicitation should be enforced in order to protect those who obey them.

${ }^{43}$ Assuming a large amount of capital is required, nevertheless if this form of solicitation is likely to be profitable and there are no rules prohibiting solicitation, regular lending agencies should supply all the capital needed. However, if solicitation and advertising are freely practiced, it is likely that the cost to a lawyer of obtaining legal business would decline. If fee could be advertised, comparative prices might become more important than first access to the potential claimant. If this situation occurred, extensive networks of informants would become uneconomical.

14 Kessel, Price Discrimination in Medicine, 1 J. L. and Econ. 20, 43 (1958); Advertising, Solicitation, and Legal Ethics, 7 Vand. L. Rev. 677, 679 (1954).

${ }^{45}$ While some writers have attacked solicitation on the grounds that it is likely to injure the client, see notes 46 and 59 infra, it can be argued that solicitation's effect upon the client has been given insufficient consideration by the courts. The lawyer-referral plans of the Brotherhood of Railroad Trainmen have been disapproved with near unanimity. In re Brotherhood of Railroad Trainmen, 13 IIl. 2d 391, 150 N.E.2d 163 (1958); Hildebrand v. State Bar, 36 Cal.2d 504, 225 P.2d 508 (1950); in re O'Neill, 5 F.Supp. 465 (E.D.N Y , 1933); cf. Doughty v. Grills, 37 Tenn.App. 63, 260 S.W.2d 379 (1952). Contra: Ryan v. Pennsylvania R. Co., 268 Ill.App. 364 (1932). See Legal Ethics and the Labor Union, 46 Ill. L. Rev. 323 (1951); Union's Lawyer Referral Plan Barred, 3 Stanford L. Rev. 549 (1951).

The plans have contained two features which courts have thought objectionable: payments by the appointed regional counsel to the union itself and payments by the counsel to union representatives when an employment contract had been secured through the representative's efforts. While the former feature would not seem essential to the functioning of the plan, the latter feature would seem to be vital. That the injured union member would benefit under these plans has not been disputed. Counsel would presumably be selected by the union on the basis of legal ability and fidelity to the injured workers' interests. Fees charged would be below those generally prevailing. Compare the twenty-five per cent contingent fee in the Mlinois case with the information set forth in note 57 infra. In the face of these benefits, the court in the Hildebrand case stated that it was not deciding the issue on the basis of public policy. It is hard to imagine on what other basis the decision could be made. Similarly, the recent decision of the Illinois Supreme Court was based on the legislative history of a statute prohibiting solicitation by laymen. By deferring to the legislature, the court, it would seem, failed to exercise its inherent power to discipline attorneys by its own standards. Ex parte Secombe, 19 How. (U.S.) 9 (1856); Givens v. Tampa Bar Ass'n, 125 Fla. 294, 169 So. 744 (1936); Opinion of the Justices, 279 Mass. 607,180 N.E. 725 (1932). 
"Overreaching," when used in connection with solicitation, involves two distinct ideas. ${ }^{46}$ First, it is argued that solicitation prevents a free choice of lawyers. Solicitation tends to be aggressive; the potential client may well be a person inexperienced in hiring a lawyer and the solicitation may occur at a time when his powers of reasoned decision are in abeyance. ${ }^{47}$ However, if a client believes he has been overreached, he may discharge the lawyer. ${ }^{48}$

The second idea subsumed under the charge of overreaching is that solicitation is offensive to the sensibilities of the client. ${ }^{49}$ The opponents of solicitation ${ }^{50}$ cite the example of the aggressive stranger invading the privacy of the hospital room ${ }^{51}$ or of a family recently bereaved. ${ }^{52}$ However, it might be argued that any resentment felt by the client is less important to him than the security of knowing that his claim is in professional hands.

The assertion that solicited clients are overcharged ${ }^{53}$ is based not only on the notion, already discussed, that the client is overreached, but also on the additional contention that competitive solicitation necessitates a network of informants which is expensive to maintain. The cost of the network, the argument runs, must eventually be borne by the clients. ${ }^{54}$ In rejoinder, however, it might be argued that aggressive solicitation is likely to drive down fees. ${ }^{55}$ Indeed, solicitation has been attacked for having precisely this effect. ${ }^{56}$ Whatever the

${ }^{16}$ Ambulance Chasing, 30 N.Y.U. L. Rev. 182, 186 (1955).

${ }^{47}$ See discussion at 684 infra.

${ }^{48}$ Except where a different rule is prescribed by statute, the client may discharge the attorney at any time and be liable only in quantum meruit. In any case the client has the power of rescinding if he can prove overreaching. Rest., Contracts $\$ \$ 470-511$ (1932).

${ }^{49}$ In addition, it can be argued that spectators of the act of solicitation will be similarly offended. This would appear to be particularly true when soliciting agents appear at the scene of a disaster. For examples of such conduct see Settlement of Personal Injury Cases in the Chicago Area, 47 Nw. U. L. Rev. 895, 903 n. 43 (1953); Ingersoll v. Coal Creek Coal Co., 117 Tenn. 263, 98 S.W. 178 (1906). However, the conduct may not be as offensive as it at first appears to be. If the spectator identifies with the injured person rather than with the tortfeasor or insurance company, his sense of outrage may be very slight.

${ }^{50}$ Ambulance Chasing, 30 N.Y.U. L. Rev. 182, 186 (1955).

${ }^{51}$ The potential client could receive protection irrespective of rules against solicitation. For example, N. Y. Penal Code (MIcKinney, 1944) \$270(b), prohibits entering a hospital to obtain a release of personal injury claims. See also note 52 infra.

52 It is conceivable that such conduct would be a violation of the right of privacy. Prosser, Torts 637-38 (2d Ed., 1955).

s3 See Ambulance Chasing, 30 N.Y.U. L. Rev. 182, 185 (1955).

5t However, assuming the simultaneous existence of solicitation and rules against it, it would seem that solicited claimants will be charged more than would otherwise be the case. There would be an extra charge for insuring against disciplinary action should the lawyer be caught soliciting.

${ }^{35}$ See Kessel, Price Discrimination in Medicine, 1 J. L. and Econ. 20, 43-44 (1958).

${ }^{56}$ In re Greathouse, 189 Minn. 51, 248 N.W. 735 (1933). 
merits of these opposing arguments, no evidence has been adduced that solicited clients are charged either higher or lower fees than unsolicited clients. ${ }^{57}$

The third element of the charge that solicitation harms clients is that soliciting lawyers do not provide adequate representation. To the extent that this argument is based on the theory that soliciting lawyers are incompetent, it has little merit. If the present rules were repealed, there seems to be no reason why competent lawyers would not solicit. ${ }^{58}$ Nor is it persuasive to argue that the soliciting lawyer is too willing to settle $e^{59}$ either because he is an expert at solicitation rather than litigation ${ }^{60}$ or because he derives his profit from large volume and rapid turnover of claims. ${ }^{61}$ Each theory presupposes that the lawyer will subordinate his client's interest to his own gain. As pointed out in a previous section, solicitation, absent rules prohibiting it, does not increase the likelihood of such lawyers.

It thus seems that there is little support for the contention that solicitation harms clients. Moreover, it might be suggested that in many cases clients are benefitted by solicitation. This is particularly true with respect to those actions -such as suits for personal injuries-in which there is often immediate pressure for settlement, ${ }^{62}$ unfamiliarity with methods of securing legal advice, ${ }^{63}$ and a lack of facilities for expert investigation of the facts relating to the claim. ${ }^{64}$ In such cases the speedy retention of counsel made possible by solicitation seems to result in important benefits to clients.

${ }^{57}$ Apparently the customary fee varies in different parts of the United States. On the East Coast fifty per cent is the normal fee, although the final charge will often be less. Lawyer's Tightrope-Use and Abuse of Fees, 41 Cornell L. Q. 683, 702 (1956). In Chicago thirty-three per cent appears standard. Settlement of Personal Injury Cases in the Chicago Area, $47 \mathrm{Nw}$ U. L. Rev. 895, 904 (1953). The Report of the Committee of Censors, op. cit. supra note 13, at 26 , states that a fifty per cent fee is exorbitant in all except intensively litigated cases. As to the difficulty in setting a maximum fee, see Lawyer's Tightrope-Use and Abuse of Fees, 41 Cornell L. Q. 683 (1956).

88 This assertion assumes that any lawyer-however much business he presently handleshas incentive to expand. However, if there is no such incentive, clients would have to resort to less competent lawyers, regardless of whether solicitation were prohibited.

${ }^{59}$ Ambulance Chasing, 30 N.Y.U. L. Rev. 182, 185 (1955); Settlement of Personal Injury Cases in the Chicago Area, 47 Nw. U. L. Rev. 895, 899, 904 (1953).

${ }^{60} \mathrm{~A}$ lawyer expert at solicitation might well have a partner who is an expert at litigation. Even if he does not, however, settlement would seem particularly advantageous to the defendant, at least in a personal injury action. For the client's earning capacity may have been reduced by the accident which gave rise to the cause of action. Compare Ratner, Advancing Money to Clients-Whether Unethical, 15 N.A.C.A.A. L. J. 410 (1955), with A.B.A. Opinions of the Committee on Professional Ethics and Grievances 619 (1957).

61 It is interesting to note that the Report of the Committee of Censors, op. cit. supra note 13 , at 52 , while conceding that abuses had occurred in the system of group settlement, concluded that the advantages of the system outweighed the disadvantages.

62 See, e.g., In re Heirich, 10 ml.2d 357, 140 N.E.2d 825 (1957).

ts This is conceded even by opponents of solicitation. Settlement of Personal Injury Claims in the Chicago Area, 47 Nw. U. L. Rev. 895, 904 (1953).

84 In re Brotherhood of Railroad Trainmen, 13 Ill.2d 391, 150 N.E.2d 163 (1958). 
Conclusion.-As indicated at the beginning of this comment, Canon 27 prohibits solicitation of any action except in very rare circumstances. 65 Fom the viewpoint of the analytic framework set forth in this comment, it would seem that a blanket prohibition can be justified only if all of the following assumptions are made: (1) that the courts exist to settle only those disputes which would otherwise be settled in a more disruptive manner; (2) that this theory of the function of the court system is sufficiently important to outweigh the policy in favor of certain actions thought particularly desirable; and (3) that, combined with the possibility that solicitation may increase the number of fraudulent claims, the theory of the courts' function is important enough to outweigh the benefits afforded the client by solicitation. If the rules prohibiting solicitation are to be judged in terms of the reasons which have been advanced in support of them, unless all of the assumptions just indicated are made, these rules will have to be reformulated on some basis other than unqualified prohibition.

The analysis of the reasons advanced against solicitation has indicated that the reformulation should be in terms of particular types of actions. As has been indicated, criteria, essential in determining the desirability of solicitation of only a few actions, result in confusion when applied to solicitation in general. Thus it was shown that it is undesirable to solicit divorce actions because of the disruptive effect upon close personal relationships. Similarly, the solicitation of personal injury claims was shown to increase the possibility of fraud; but it was also shown that solicitation of such suits benefitted some clients. These considerations, however, were shown not to apply to all types of actions.

An additional factor favoring reformulation of the existing rules is the fact that those rules seem to have lost some support among members of the bar. ${ }^{66}$ Since this has occurred, it would appear that prosecution of a lawyer for solicitation may well imply prosecution for some other phase of his professional life. ${ }^{67}$ As a result, disenchantment with the rules may increase. If the rules are reformulated in a critical spirit, they would likely be given stronger support.

Finally, as indicated in the introduction to this comment, there are various considerations, not often articulated, which underlie the present rules prohibiting solicitation. A move to reformulate the rules will call for a critical, yet sympathetic, analysis of those unarticulated considerations. Then a final evaluation of solicitation will be possible.

$\$ 5$ See note 8 supra.

${ }^{66}$ Two arguments support this conclusion: the frequence and openness with which the rules are violated and the pessimism of writers friendly to the traditional rules. As to the first point, it has been estimated that in one metropolitan region ninety-five per cent of the serious personal injury claims were solicited. Settlement of Personal Injury Cases in the Chicago Area, $47 \mathrm{Nw}$. U. L. Rev. 895, 899 (1953). As to the second point, ultimate solution of the solicitation problem has been seen only in the abolition of actions solicited. Drinker, Legal Ethics 64 (1953); Report of the Committee of Censors, op. cit. supra notes 13 and 59.

67 For example, on occasion it has seemed that the lawyer was prosecuted primarily because of his aggressive representation of plaintiffs against large corporations. State v. Murrell, 74 So. 2d 221 (Fla., 1954); In re Heirich, 10 Ill.2d 357, 140 N.E.2d 825 (1957); Crownhart, J. dissenting in State v. Cannon, 199 Wis. 401, 226 N.W. 385 (1929). 